\title{
ヌードマウス移植腫瘍におよぼす純エタノール局注の影響
}

\author{
溝口正枝 加藤俊男 小川久美子 名古屋市立大学医学部第一病理学教室 \\ 長尾静子 高橋英久 藤田保健衛生大学衛生学部実験動物学教室 \\ 荒井昌之 藤田保健衛生大学衛生学部病理学教室
}

\section{THE EFFECTS OF ETHANOL ON A TRANSPLANTED RAT LIVER TUMOR IN ATHYMIC NUDE MICE}

Masae Mizoguchi, Tosio Kato, and Kumiko Ogawa First Department of Pathology, Nagoya City University Medical School

Shizuko Nagao and Hisahide Takahashi Fujita Health University School of Hygiene, Department of Experimental Zoology

Masayuki Arai Fujita Health University School of Hygiene, Department of Pathology

\begin{abstract}
The effects of ethanol on a liver tumor which was transplanted into athymic nude mice were investigated. The original liver tumor was obtained from a F344 rat, initiated with diethylnitrosamine (DEN), and subsequently administered 2-acetyl-aminofluorene (2-AAF), and established as a tumor line in rnu/rnu rats. Pieces of serially transplanted liver tumor were inoculated into 34 ICR nude, 5week-old, mice. After one week, these were divided into two groups, one (Group 1) receiving a $0.2 \mathrm{ml}$ injection of ethanol in the transplanted and the afer (Group 2) given $0.2 \mathrm{ml}$ saline. Group 3, without the tumor transplanted was administered ethanol as a control. Subgroups of animals were killed at days 2, 5,10 , and 30 . In group 1 , at day 2 after the ethanol injection areas of tumor showed severe necrosis with crust formation. In contrast, those not receiving the ethanol injection demonstrated intact transplants. In group 1, necrotic portions were gradually absorbed and development of tumors was apparent by day 30 , but the sizes of individual lesions were smaller than in the group given saline alone. Thus ethanol clearly inhibited the growth of transplanted liver tumor. The results suggest that ethanol injection might be effective as a treatment for hepatocellular neoplasms. (J Toxicol Pathol $7: 61 \sim 65,1994$ )

Key words : Ethanol injection, Liver tumor, Transplantation, Athymic nude mice
\end{abstract}

\section{はじめに}

Flanagan ${ }^{1}$ ならびに Pantelouris² れた突然変異ヌードマウスは，無毛，無胸腺を第 一の特徵とし,免疫欠損のため異種動物間の組織, 臟器の移植が比較的容易でありかなりの割合で生 着している。ヌードマウスへのヒト癌の移植につ いては, 1969 年 Regard and Povlsen ${ }^{3}$ が成功して

Accepted for publication : August 19, 1993

Mailing address : Masae Mizoguchi, First Department of Pathology, Nagoya City University School of Medicine, 1 Kawasumi, Mizuho-cho, Mizuho-ku, Nagoya 467, Japan.
以来, 数多く報告されている4-8。発癌分野におい ても，種々の移植系腫焬の確立により，悪性腫瘍 の本体の解明にヌードマウスは重要な役割を果た しており,さらにその移植された腫瘍を基に抗癌 剤の効果の検討9-11 などにも応用され，動物モデ ルとして重要な地位を占めている。

一方, 1953 年 Rowette Research Institute $の$ outbred coloneyより見いだされたヌードラット (rnu/rnu) は, 無毛, 無胸腺で免疫学的にヌード マウスとほほ同様であり，腫場の移植に使用され るようになってきた

我々はF344 系雄ラットに化学発癌物質を投与 
して誘発した肝腫瘍を原腫煬としてヌードラット 皮下に移植し，その組織学的推移を検索し報告し たが16，今回はさらに継代移植中移植腫湯をヌー ドラットからヌードマウスへ移植し，発育した腫 啺に対するアルコールの直接注入による影響を検 討したので報告する。

\section{実験材料ならびに方法}

\section{1. ヌードラット}

藤田保健衛生大学実験動物センター（換気： オールフレッシュエアー12 回/時, 温度 $23 \pm 1^{\circ} \mathrm{C}$, 湿度 $55 \pm 5 \%$ ，照明サイクル明暗 12 時間)で飼育, 兄林交配により系統維持しているヌードラット, 3 〜6 週齢の $\mathrm{rnu} / \mathrm{rnu}$ (雌雄) 2〜4 匹を選び, 4〜8 週ごとに継代移植実験に供した。期間中, 飼料は, オリエンタルCMF（オリエンタル醉母社製），飲 料水は, 滅菌蒸留水を使用した。実験期間中, 飼 料, 飲料水ともに，自由に摂取させた。

\section{2. 原肝腫湯の作製}

F344 雄ラット（日本チャールスリバー，神奈 川), 4 週齢に diethylnitrosamine (DEN) (東京化 成） $200 \mathrm{mg} / \mathrm{kg}$ を 1 回腹腔内投与, 1 週間の体薬 後, $100 \mathrm{ppm}$ の割合で 2-acethylaminofluorene（2$\mathrm{AAF}$ ，東京化成）を混合した飼料（オリエンタル MF)を与え， 34 週目にラットを屠殺，無菌的に肝 臓の腫瘍部を摘出, 移植原腫煌とした。

\section{3. 瘇瘍移植法}

\section{1) 初代移植}

F344 ラットより無菌的に摘出した原肝腫場を, 直ちに少量の培湌液中に浸け，滅菌した小ハサミ で細切し，トラカール（夏目製作所）に積めヌー ドラットの左右両背部皮下に注入移植した。移植 した細切片が流れでないことを確認し，ラットを ケージに戻した。

2) 継代移植

4 週前後で発生した腫㕫が，十分移植可能な大 きさ（腫痬推定重量が $1 \times 10^{3} \mathrm{mg}$ 以上）であるこ とを確め,ネンブタール麻酔下で, 無菌的に摘出, 培養液中で細切後トラカールに詰め, 次世代の ヌードラットの両背部に移植した。
3） ヌードラットの移植腫塞のヌードマウスヘ の再移植とエタノール注入

12 代ヌードラットの移植肝腫場を, 同様な方法 でトラカールに細切した腫瘍を詰め，5週齢の ICR ヌードマウス(チャールスリバー), 34 匹の右 背側部皮下に移植した。

1 群 16 匹には, 腫瘍移植後 1 週間目にツベルク リン注射器で純エタノール $0.2 \mathrm{ml}$ を移植腫瘍内 に注入した。2 群の 9 匹には, 対照群として腫媗移 植後生理食塩水を同様の方法で投与し, また 3 群 の 9 匹には，腫淿を移植することなくエタノール のみを投与した。各群とも注入後 $2,5,10,30$ 日目 にエーテル麻酔下に屠殺, 局注部を含め腫煬を摘 出し, 病理組織学的に検索を行った。

4. 测定法

1) 体重測定

毎週 1 回，床がえ時に動物の体重を測定し，急 激な瘦せなど，体重減少をみた動物は屠殺した。

2）腫場推定重量の測定

毎週 1 回，ノギスを使って背部皮下に発生した 腫瘍の長, 短径および高さを測定し, Ovejera ${ }^{17}$ の 方法 ( $\mathrm{a} \times \mathrm{b}^{2} / 2 \mathrm{mg}, \mathrm{a}$ : 長径, $\mathrm{b}$ : 短径) て腫堭推定 重量を算定した。

\section{5. 組織標本の作製}

摘出した腫場の一部は電顕用固定液に保存, そ の他は $10 \%$ ホルマリン液中にて固定を行い, 通常 の方法でパラフィン包理, 薄切標本を作製し, HE 染色, PAS 染色, アルシャン青染色を行い, 必要 に応し，PAS-オレンジ G 染色を行った。

\section{結 果}

\section{1. 体重曲線}

各群とも平均体重はほほ順調に増加したが, 移 植 3 週目頃から減少傾向が見られた。

\section{2. 腫瘍推定重量}

生理食塩水投与群では明らかに増加傾向を示し たが，エタノール注入群では，注入後 3 日後より 減少傾向を示した。しかし移植 2 週間目頃より,再 び増加傾向となった。生理食塩水投与群では 30 日 後では平均腫晹推定重量が $4,900 \mathrm{mg}$ であるのに

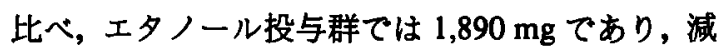
少傾向を表した。 


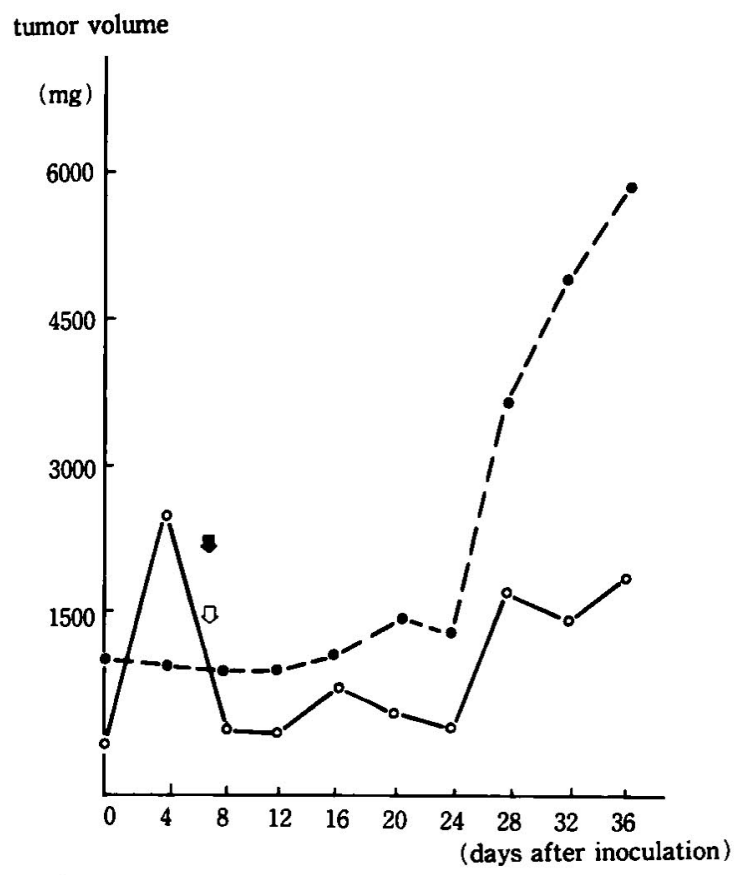

Fig. 1. Serial changes in transplanted liver tumor volume in nude mice.

$\downarrow$ : ethanol injection

\&: saline injection

$\mathrm{O}-\mathrm{O}$ : ethanol injected group

$\bullet$ : saline injected group

\section{3. 肉眼的所見}

ヌードマウスに肝腫湯を移植後， 1 週間目に腫 場部にエタノールを局注した第 1 群は，いずれも 局所に強い壊死，潰湟を形成した。一方，腫湯部 に生理食塩水を局注した第 2 群の動物は, 注入し た部にごく軽度の壊死を認めたが，腫瘍の增大傾 向は変わらず半球状の集塊が著明にみられた。移 植を行わずに背部皮下にエタノールのみを注入し た動物は，ごく軽度の表皮の剝離および皮下の壊 死を認めるのみであった（Fig. 2)。

\section{4. 組織学的所見}

DEN 由来の原腫瘍は腫湟細胞が索状に配列 し，その周囲に内皮細胞が取り囲んでいる典型的 な索状型肝細胞癌の像を示した。

エタノール局注群において，2 日目，5 日目には 注入局所に強い壊死巣の形成, その周囲に好中球 の出現がみられた (Fig. 3)。生理食塩水注入の第 2 群も壊死巣の形成が見られたが第 1 群に比して 軽度でその後壊死組織は吸収され腫湯組織の残存

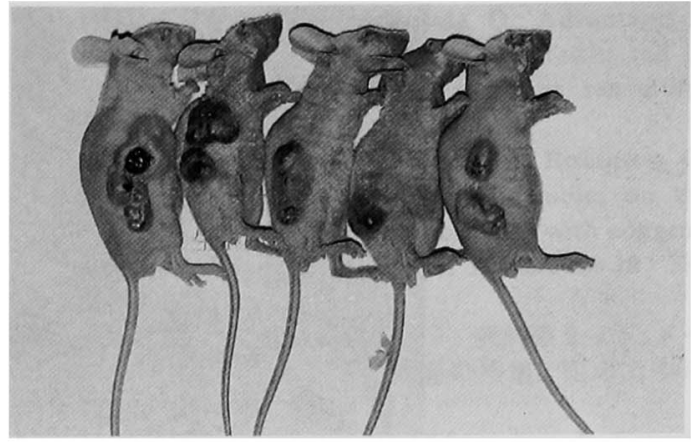

a)

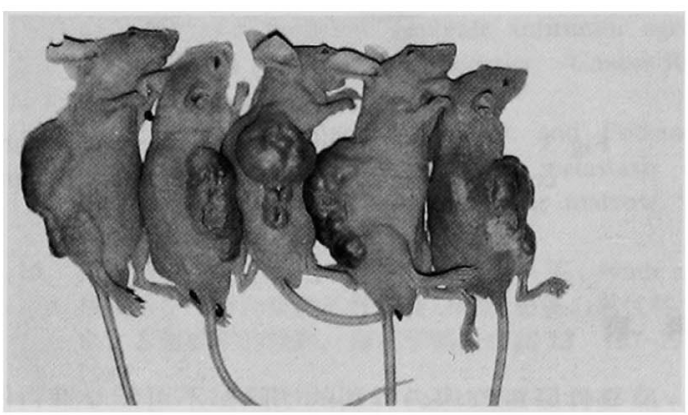

b)

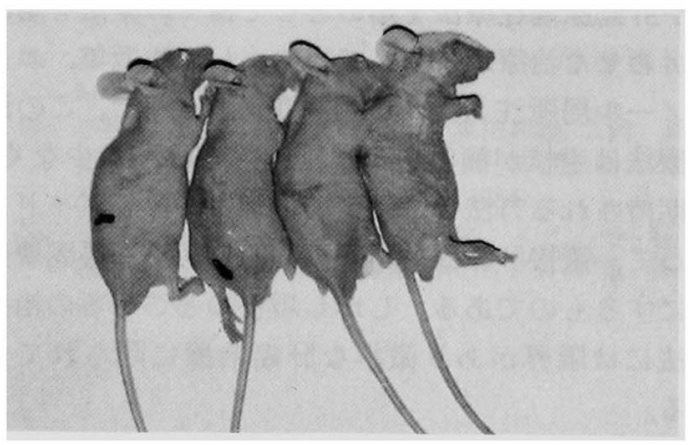

c)

Fig. 2. Macroscopic findings for nude mice bearing with transplanted liver tumor, as following.

a) Ten days after ethanol injection.

b) Ten days after saline injection.

c) Ten days after ethanol injection without any transplanted liver tumors.

が見られた。第 1 群のエタノール注入局所は長期 間壊死組織が持続してみられ，その周囲にはリン パ球の浸潤, 異物巨細胞の出現も見られた。エ夕 ノール注入から, 30 日後には壊死部は脱落し, 再 び腫县の発育増殖がみられたが, 生理食塩水注入 群に比べて腫瘍のサイズは小さかった。 


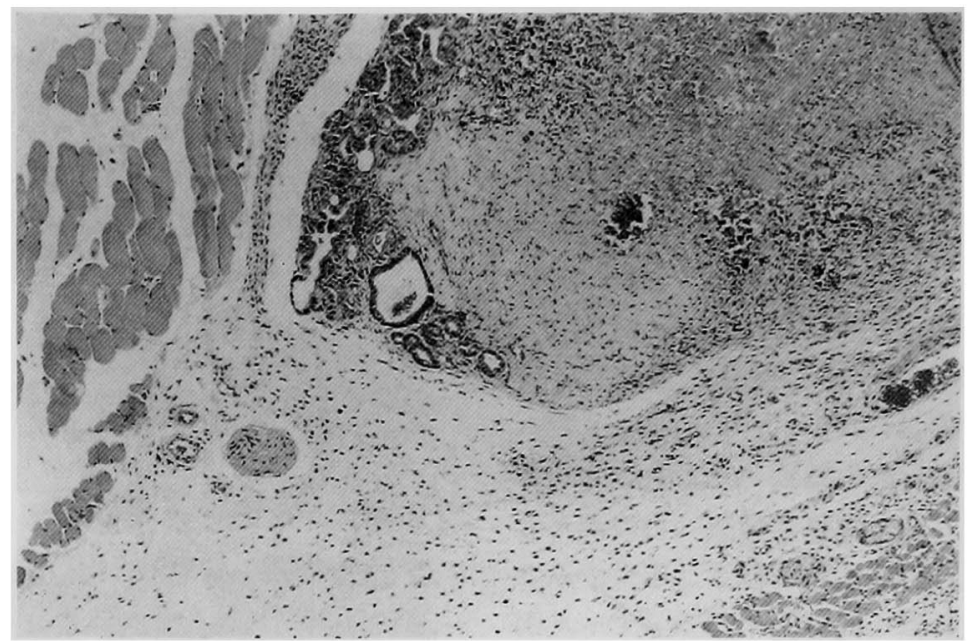

Fig. 3. Histologic findings. Five days after ethanol injection, a transplanted liver tumor lesion demonstrates coagulation necrosis and inflammatory cell infiltration.

\section{考 察}

原発性肝細胞癌の外科的切除が不可能な進行例 に対する内科的治療として, 肝動脈内抗癌動注法 や肝動脈塞栓療法を始めとして種々の療法を組み 合わせた治療が行われている。しかし近年, エタ ノール局所注入法が注目を集めている18。この治 療法は手技が簡単なうえ副作用の心配も少なく， 期待される方法で，超音波による波形をガイドと して, 直接肝臓部に穿刺し, 腫瘍組織を凝固壊死 にするものである。しかし現在のところこの治療 法には限界があり微小な肝癌治療に限られてい る。

エタノール局所注入療法の効果としては, エタ ノールによる癌細胞の壊死固定とその後に生じる 線維性隔壁の形成である。エタノール注入量と索 状型肝細胞癌の関連について, 杉浦ら ${ }^{19}$ は, ウサギ 正常肝に, 純エタノールを $0.5 \sim 2.1 \mathrm{ml}$ 注入し $2 \mathrm{ml}$ では, $1.5 〜 2 \mathrm{~cm}$ の範囲で壊死を認めており, 壊死 組織の病理学的所見では, 直後において類洞の輪 郭を残して肝細胞の核や細胞質の崩壊, 散在性の 出血が見られ, 1 週間後では, 壊死部で肝細胞の輪 郭が消失し,脈管内の線維素血栓の形成が見られ, また境界部では, 線維芽細胞の増殖が見られたと 報告し, 松崎ら ${ }^{20}$ は 24 時間後では, 注入部肝細胞 の多くは凝固壊死に楩り，48 時間後では，壊死部 周囲に線維の軽度増加を認め, その線維性隔壁の
形成が見られたと述べている。また，エタノール 濃度は純エタノールで最大の壊死効果を見たと報 告している。

今回の実験では，以前より，ヌードラットに継 代移植していた DEM，2-AAF 誘発の移植肝腫 場 ${ }^{16}$ をヌードマウスに再移植し，移植腫瘍に対す るエタノール局注の効果を検索した。腫湯推定重 量は生理食塩水注入動物においては, 1 力月後で は $4,000 \mathrm{mg}$, 腫場/体重比, 22.1\%でエタノール注 入群では, $1,890 \mathrm{mg}$, 腫瘍/体重比 $9.3 \%$ と腫煌增殖 に対して明らかな抑制作用が認められた。組織学 的には,エタノール局注群ては， 5 日目には局注部 においては強い凝固壊死が見られたが周囲には， 腫瘍細胞の残存が認められ, 境界は線維組織の增 殖も見られた。

エタノールには熱作用と凝固作用の両方があ り，本実験でも移植せずにエタノールのみを局注 した動物においても,はじめは強い凝固壊死が 0.2 $\mathrm{ml}$ という少量で認められたが，1 カ月後にはほと んど痕跡化したことからも, エタノールは, 正常 組織に対して障害作用はなく腫浧に対しても一過 性のものと判定された。今回の結果, 少なくとも 微小な肝腫瘍に対してかなり効果のあることが示 唆された。今後さらにエタノール作用が長期間持 続するような投与法の改善を図り局所部の腫瘍の 完全脱落を追及して行くことが大切であると思わ れる。 


\section{文 献}

1. Flanagan, SP: A new hairless gene with pleiotropic effects in the mouse. Genet Res 8: 295, 1966.

2. Pantelouris, EM: Absence of thymus in a mouse mutant. Nature 217: 370, 1968.

3. Rygard, J and Povlsen, CO : Heterotransplantation of a human malignant tumor to nude mice. Acta Pathol Mocrobiol Scand 77 : 758-760, 1969.

4. Povlsen, $\mathrm{CO}$ and Rygaard, $\mathrm{J}$ : Heterotransplantation of human adenocarcinomas of colon and recrum to the mouse mutant nude: A study of nine consecutive transpantations. Acta Pathol Microbiol Scand 79 : 159-169, 1971

5. Williams, AW and McCulloch, P: Human cancer and other transplants in the nude mouse. J Pathol 122 : 225-229, 1977.

6. Caselitz, J, Lunau, U, Hamper, K, Walther, B, and Schmiegelow, P : The pleomorphic adenoma of salivary glands transplanted on athymic mice. Virchows Arch [A] 408: 191-209, 1985.

7. Anderson, LM and Rice, JM: Tumorigenesis in athymic nude mouse skin by chemical carcinogens and ultraviolet light. J Natl Cancer Inst 78 : 125133, 1987.

8. Upp, JR Jr, Beauchamp, RD, Townsend, CM Jr, Barranco, SC, Singh, P, Rajaraman, S, James, E, and Thompson, JC: Inhibitation of human gastric adenocarcinoma xenografted growth in nude mice by $\alpha$-difluoromethylornine. Cancer Res 48: 3265$3269,1988$.

9. 菊地寞昭, 朝村光雄, 蒲生真紀夫: SRCA（Subreanal Capsule Assay）による制癌剤感受性試験の 基礎的検討. 癌と化療 15：499-504，1989.

10. 古沢明彦：ヌードマウス可移植性肝細胞癌に対する 徐放性制癌剤の単独及び併用効果, 肝臓 30：20-27, 1989.
11. Hida, S, Okada, K, and Yosida, O: Advantages in combination chemotherapy using cisplastin and its analogues for human testicular tumor xenografts. Jpn J Cancer Res 81 : 425-430, 1990.

12. Brooks, CG, Webb, PJ, Robins, RA, Robinson, G, Baldwin, $R$, and Festing, MFW : Studies on the immunobiology of $\mathrm{rnu} / \mathrm{rnu}$ nude rats with congenital aplasia of the thymus. Eur J Immunol 10: 58$65,1980$.

13. 丸尾幸嗣, 上山義人, 桑原裕子 : 無胸腺ラット(ヌー ドラット) へのヒト悪性腫場の移植. 医のあゆみ 116: 1004-1006, 1981.

14. Neuwelt, EA, Frenkel, EP, D'Agowtino, N, Carney, DN, Minna, JD, Barnett, PA, and McCormick, CI : Growth of human lung tumor in the brain of the nude rat as a model to evaluate antitumor agent deliery across the blood-brain barrier. Cancer Res 45: 2827-2833, 1985.

15. Kjønniksen, I, Nesland, JM, Pihl, and Fodstad, $\phi$ : Nude rat model for studying metastasis of human tumor cells to bone and bone marrow. J Natl Cancer Inst 82 : 408-412, 1990.

16. 長尾静子, 荒井昌之, 舟橋正範, 高橋久英: Nude rat 移植系を用いた実験的肝葴及び膀胱腫瘍の継代移植 による組織学的検討. 藤田学園医会誌 13：187-191, 1989.

17. Ovejera, AA, Houchens, DP, and Banker, AD : Chemotherapy of human tumor xenografts in genetically athymic mice. Ann Clin Lab Sci 8 : 5056. 1978.

18. 真島康雄, 谷川久一：エタノール局注療法. Medicina 24: 1616-1618, 1987.

19. 杉浦信之, 高良健司, 大藤正雄, 奥田邦雄, 広岡 昇 : 超音波映像下経皮的腫㡍内エタノール注入による小 肝細胞癌の治療. 肝荿 25: 920, 1984.

20. 松崎研一郎, 横井幸男, 黑田博之：エタノール局所 注入後の肝組織壊死と線維化に関する検討. 肝蔵 30 : 43-48, 1989. 